\title{
pH effect on the susceptibility to parasitoid infection in the marine diatom Coscinodiscus spp. (Bacillariophyceae)
}

\author{
Stefanie F. Kühn · Stephanie Köhler-Rink
}

Received: 30 January 2007 / Accepted: 3 January 2008 / Published online: 29 January 2008

(C) Springer-Verlag 2008

\begin{abstract}
The $\mathrm{pH}$ on the frustule of individual cells of the marine centric diatoms Coscinodiscus granii and Coscinodiscus wailesii (Bacillariophyceae) was measured with $\mathrm{pH}$ microsensors in culture media with increasing $\mathrm{pH}$ values of $8.04,8.14$, and 8.22, respectively. In 85-96\% of the C. granii cells the $\mathrm{pH}$ on the frustule was up to 0.4 units higher than that of the medium, reaching a maximum $\mathrm{pH} 8.95$. Only in $2-3 \%$ the surface $\mathrm{pH}$ exceeded that of the medium by up to $0.7 \mathrm{pH}$ units. These results strongly suggest that diatoms in batch cultures differ, at least temporarily, in their individual photosynthetic activities. Infection experiments with the parasitoid nanoflagellate Pirsonia diadema (Stramenopile) showed that flagellates failed to infect when the culture $\mathrm{pH}$ was 8.8 and above. $\mathrm{pH}$ measurements on freshly infected C. granii showed that the prevalence of infection was higher in tendency on diatoms with low surface $\mathrm{pH}$. Application of these results to parasitoid-diatom interactions in natural waters suggests that within phytoplankton populations a strong photosynthetic activity might prevent diatom cells temporarily from infection by $\mathrm{pH}$-sensitive parasitoids.
\end{abstract}

\section{Introduction}

Most photosynthetically active diatoms take up $\mathrm{CO}_{2}$ (carbon dioxide), whereas others can also take up $\mathrm{HCO}_{3}{ }^{-}$

Communicated by M. Wahl.

S. F. Kühn ( $\square)$

Marine Botany (FB2), University of Bremen,

PO Box 330 440, 28334 Bremen, Germany

e-mail: skuehn@uni-bremen.de; stefanie.kuehn@t-online.de

S. Köhler-Rink

Max-Planck-Institute for Marine Microbiology,

Celsiusstr. 1, 28359 Bremen, Germany (bicarbonate) (Tortell et al. 1997; Matsuda et al. 2001). Photosynthetic removal of $\mathrm{CO}_{2}$ causes an increase of $\mathrm{pH}$ of the boundary layer of the medium. Thus, phytoplankton mass developments, either in culture or in the field, may cause a general increase of $\mathrm{pH}$. In phytoplankton batch cultures, $\mathrm{pH}$ values of 9.5 and above, can be reached in the stationary phase (Goldman et al. 1982; Taguchi et al. 1987). Natural seawater has an average $\mathrm{pH}$ of approximately 8.0 8.2 but during phytoplankton blooms in the German Bight, North Sea, it can increase to pH 8.7 (Pegler and Kempe 1988).

It is generally assumed that all cells in unialgal diatom cultures are more or less identical in their physiological properties. This assumption may not necessarily hold true as was indicated by infection experiments in which the marine parasitoid nanoflagellate Pirsonia diadema Kühn (Stramenopile) infected, and eventually consumed, the large diatoms Coscinodiscus granii and Coscinodiscus wailesii (Bacillariophyceae). Pirsonia clearly showed interspecific selectivity between host species and intraspecific selectivity within unialgal host cultures (Kühn 1998). Laboratory experiments indicated that the photosynthetic activity of individual $C$. wailesii cells might affect their susceptibility to infection (Kühn 1998). While in cultures kept in light some cells seemed to be most attractive for further infections, about $1 \%$ of the diatoms remained uninfected for some time. In darkness, all cells were infected equally. It was suggested that photosynthesis enhances the formation of individual physiological properties of diatoms leading to intraspecific variability of susceptibility.

Pirsonia infecting Coscinodiscus gradually ingest diatom cell contents. A feeding flagellate will divide approximately $6 \mathrm{~h}$ after attachment for the first time, without having severely affected the internal structure of the diatom protoplast. Multiple infections, however, will kill a diatom 
within a few hours. If the photosynthetic activity of individual diatoms influences the infection behaviour of Pirsonia flagellates, the external $\mathrm{pH}$ on the frustule should be an indicator for their susceptibility to infections. Microsensors for $\mathrm{pH}$ and oxygen have successfully been used to determine variations of $\mathrm{pH}$ and oxygen saturation on the frustule and the plasma membrane of individual $C$. wailesii cells during light and dark shifts (Kühn and Raven 2008).

Generally, Pirsonia flagellates are attracted by intact C. wailesii (Kühn 1998) but rapidly avoid manually damaged crushed cells (unpublished). We assumed that this escape behaviour was caused by the acidic vacuolar sap. Therefore, it was also of interest to test if $\mathrm{pH}$ microsensors could be used to measure the acidity of the vacuole.

In the present study we investigated (a) the effect of $\mathrm{pH}$ values in Coscinodiscus cultures on the ability of $P$. diadema to successfully infect host cells, (b) the $\mathrm{pH}$ on the surface (frustule) of individual photosynthesising diatoms with the aid of $\mathrm{pH}$ microsensors, (c) potential effects of surface $\mathrm{pH}$ on the ability of the parasitoid to infect successfully and (d) the $\mathrm{pH}$ of the diatom vacuole.

\section{Materials and methods}

\section{Cultures}

Cultures of the marine diatom $C$. granii Gough and $C$. wailesii Gran and Angst were established from cells isolated off List/Sylt in the North Sea, German Bight. Cultures were maintained in modified F/2 (Guillard and Ryther 1962) at $15^{\circ} \mathrm{C}$ on a $16: 8 \mathrm{~L}: \mathrm{D}$ cycle. The salinity was adjusted to 30 PSU. Microsensor experiments were carried out at room temperature $\left(21-22^{\circ} \mathrm{C}\right)$. Cell diameters were in the range of $300-400 \mu \mathrm{m}$. As in natural populations, diatom division was not synchronised. Pirsonia diadema was isolated in 1993 from the same site and cultivated according to Kühn et al. (1996). Infection experiments were carried out under nonturbulent conditions, i.e. culture vessels remained stationary and were only shaken cautiously before sampling. Previous experiments had shown that that infection dynamics differed between Coscinodiscus cultures maintained under turbulent conditions (rolling tanks) and those maintained under nonturbulent conditions (Kühn and Hoffmann 1999). It was necessary to count live samples to distinguish between infected and uninfected diatoms (preservation with Lugol's solution led to the detachment of Pirsonia flagellates from the diatoms). This limited the feasible number of replicates.

\section{$\mathrm{pH}$ microelectrodes}

$\mathrm{pH}$ was measured with $\mathrm{pH}$ liquid ion exchange (LIX) microelectrodes (de Beer et al. 1997) in combination with a calomel reference electrode (Radiometer 401, Denmark), connected to a high-impedance $\mathrm{mV}$ meter (Mascom, Germany). The tip diameter of the microelectrodes was 6-10 $\mu \mathrm{m}$. Electrodes were calibrated at room temperature in standard pH buffers (pH 7 and 9.26) (Mettler Toledo), and the signals were recorded on strip chart recorder (Görz, Germany). pH sensors responded within milliseconds.

Experimental set up for microsensor measurements

Experiments were carried out in a small Plexiglass chamber filled with F/2 or artificial seawater. Since Coscinodiscus spp. cells tended to sink down, the bottom of the chamber was covered with a $\sim 5$-mm thick layer of agar (1\% prepared from $\mathrm{F} / 2$ with $\mathrm{pH}$ according to the experiment). This was the best approximation to simulate a natural environment where cells are surrounded by seawater. The agar served at the same time as a protection against damage of the microsensor tip. Microsensors were positioned by a manually operated micromanipulator (Märtzhäuser, Germany) (Fig. 1). The position at the diatom surface was determined by observation of the microsensor under a dissection microscope. Inclination of microsensor was $10^{\circ}-20^{\circ}$ to diatom surface. Light source was a fiber optic halogen lamp (Schott KL-1500, Germany), and quantum irradiance (400-700 nm) was measured with a quantum scalar irradiance meter (Biospherical Instruments, QSL101, USA). Experiments were carried out with an irradiance of 160-170 $\mu \mathrm{mol}$ photons $\mathrm{m}^{-2} \mathrm{~s}^{-1}$.

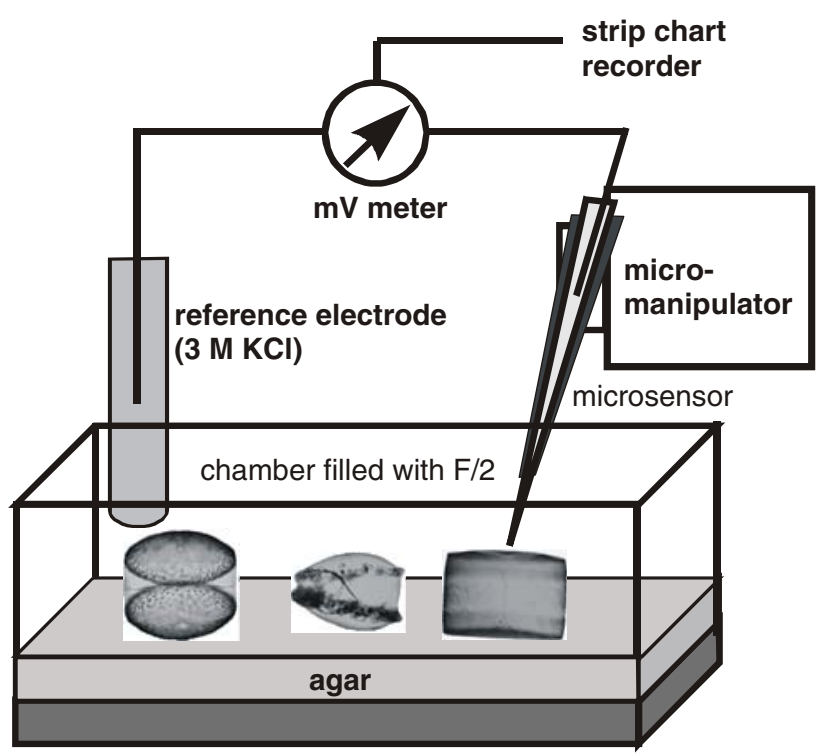

Fig. 1 Experimental set-up of microsensor experiments. Diatoms were placed in small chambers on agar. Photographs show a "double" cell of Coscinodiscus granii (left), a "single" C. granii cell infected by Pirsonia diadema (middle) and $C$. wailesii (right) 
$\mathrm{pH}$ development in culture medium and Coscinodiscus wailesii cultures (Experiment 1)

For $\mathrm{pH}$ measurements in culture medium, $150 \mathrm{ml}$ of $\mathrm{F} / 2$ were filled in $250 \mathrm{ml}$ Erlenmeyer flasks and covered with aluminium foil. The starting volume of diatom batch cultures was $700 \mathrm{ml}$ in $1000 \mathrm{ml}$ Erlenmeyer flasks. In all flasks, the initial $\mathrm{pH}$ values were adjusted with $0.1-1 \mathrm{~N}$ $\mathrm{HCl}$ or $\mathrm{NaOH}$ to $\mathrm{pH} 6.8,7.2,7.6,8.0,8.7$ and 9.5. The $\mathrm{pH}$ was determined daily the same time $( \pm 1 \mathrm{~h})$. Ten $\mathrm{ml}$ were removed every day from the culture for cell counts.

\section{Infection experiments with Pirsonia diadema and Coscinodiscus granii (Experiment 2)}

Experiments were carried out in 78-ml Volume Disposable Tissue Culture Flasks with $35 \mathrm{ml} \mathrm{C}$. granii culture (initial

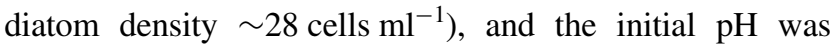
adjusted to 8.0. On five successive days, diatom culture media were inoculated with one $C$. granii cell equally infected by $P$. diadema. Ten replicates were used for each day. In the following days, infected cultures were counted daily at the same time $( \pm 1 \mathrm{~h})$, and the $\mathrm{pH}$ was measured. The numbers of infected and uninfected cells were determined directly in culture flasks using a self-constructed grid.

$\mathrm{pH}$ on diatom frustules (Experiment 3)

Measurements started 20-30 min after transferring diatoms into the experimental chamber to allow cells to adjust to their new environment. The $\mathrm{pH}$ of the $\mathrm{F} / 2$ medium varied between 7.98 and 8.29. For analysis, measurements in medium with $\mathrm{pH} 7.98-8.09,8.10-8.19$ and 8.20-8.29 were pooled together. Since the $\mathrm{pH}$ at the cell surfaces depended on the irradiance (manuscript in preparation) experiments were carried out at one light intensity only (160-170 $\mu \mathrm{mol}$ photons $\left.\mathrm{m}^{-2} \mathrm{~s}^{-1}\right)$.

$\mathrm{pH}$ on frustules of infected cells vs. non-infected cells (Experiment 4)

Coscinodiscus granii cultures were infected in Erlenmeyer flasks with varying inoculate of $P$. diadema flagellates. The $\mathrm{pH}$ of the medium was between 7.98 and 8.26. For analysis, measurements in medium with $\mathrm{pH} 798-8.09,8.10-8.19$ and 8.20-8.29 were pooled together.

Approximately $1 \mathrm{~h}$ after the attachment of a Pirsonia flagellate to Coscinodiscus the diatom showed first signs of infection, i.e. chloroplasts began to slowly accumulate around the infection site. The internal structure of the diatom remained intact for several hours if only one flagellate was feeding but was strongly affected within a short time $(>2 \mathrm{~h}$ ) when several flagellates were consuming cell contents. To ensure the firm attachment of flagellates to diatoms, infected cultures were transferred approximately $1 \mathrm{~h}$ after incubation into the experimental chamber. Surface $\mathrm{pH}$ was determined within 2-3 h after inoculating Coscinodiscus cultures with Pirsonia to avoid that photosynthetic activity was affected by progressive infection. It was only distinguished between the infected and uninfected diatoms and the number of attached flagellates was not considered.

\section{Vacuolar $\mathrm{pH}$ in Coscinodiscus wailesii (Experiment 5)}

Coscinodiscus wailesii cells had a diameter of $\sim 400 \mu \mathrm{m}$. For measurements, the microsensor was adjusted at the depression in the valve centre before the cells were rapidly impaled (when the microsensor was pressed down on the valve edge the cells often slipped away).

\section{Results}

Experiment 1: $\mathrm{pH}$ in $\mathrm{F} / 2$ culture medium and $C$. wailesii cultures

In culture medium (without diatoms) with an initial $\mathrm{pH}$ of 9.5 the $\mathrm{pH}$ decreased within 11 days more or less continuously by about one unit to $\mathrm{pH} 8.5$, whereas in that with an initial $\mathrm{pH}$ of 6.8 the $\mathrm{pH}$ increased within the first 4 days to $\mathrm{pH} 7.4$ and then remained constant at this value (Fig. 2).

In $C$. wailesii cultures that had been adjusted to an initial pH of 9.5 all cells died within the first 2 days. When the initial $\mathrm{pH}$ was 8.7 , the diatoms survived and the $\mathrm{pH}$ remained at $\sim \mathrm{pH} 8.7$ until the culture was discontinued after 11 days (Fig. 3). In the other cultures starting from $\mathrm{pH} 8$ and lower, the maximum value of $\mathrm{pH} 8.8$ was reached after up to

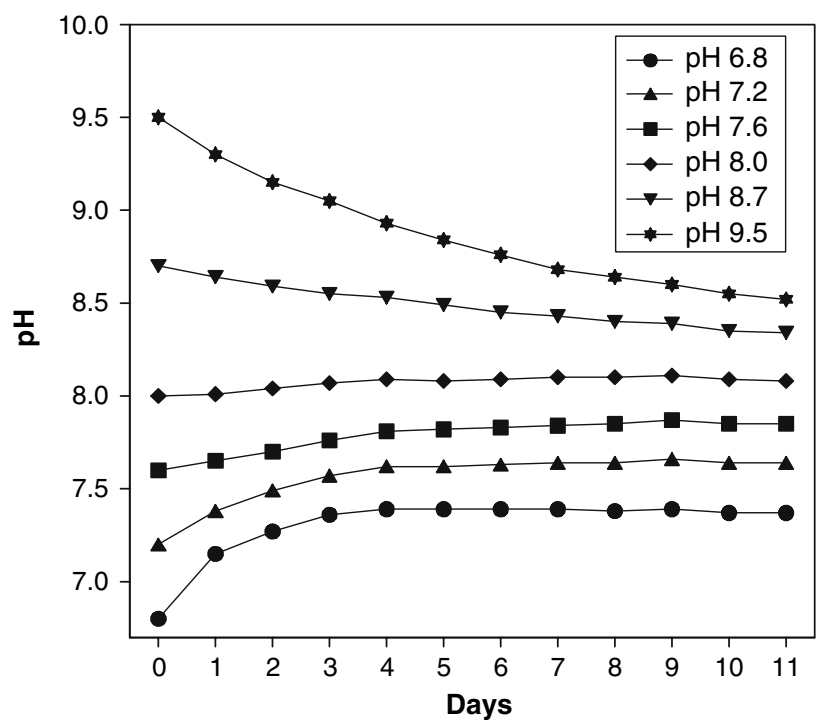

Fig. 2 Development of $\mathrm{pH}$ in seawater adjusted to initial $\mathrm{pH}$ values varying from 6.8 to 9.5 


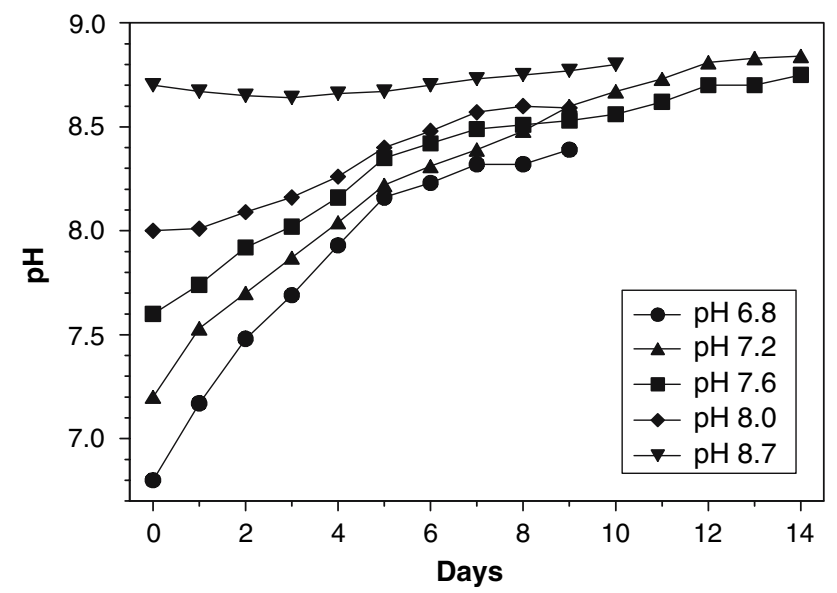

Fig. 3 Development of $\mathrm{pH}$ in Coscinodiscus wailesii cultures adjusted to initial $\mathrm{pH}$ values varying from 6.8 to 8.7

14 days. In contrast, in similar experiments the maximum $\mathrm{pH}$ in cultures of the marine diatoms Thalassiosira punctigera was 9.1 (not shown).

\section{Experiment 2: Infection of $C$. granii by Pirsonia}

The infection dynamics depended on the $\mathrm{pH}$ in the experimental cultures at the time when the P. diadema was added. $\mathrm{pH}$ changes caused by infection were principally the same in all cultures but differed too much in their temporal development to be treated statistically. Therefore, three replicates (out of ten) are depicted to demonstrate the interaction of infection rates and $\mathrm{pH}$ changes. A C. granii culture with an initial $\mathrm{pH} 8.0$ was inoculated on day three with P. diadema when the $\mathrm{pH}$ had risen to 8.3 (Fig. 4a). On day six, the $\mathrm{pH}$ had increased to 8.6 , and $70 \%$ of the diatoms were infected. The following day, all diatoms were infected and the $\mathrm{pH}$ decreased again. The flagellates also successfully infected all remaining diatoms when the $\mathrm{pH}$ had risen to almost 8.8 (Fig. 4b).

In comparison, at an ambient $\mathrm{pH}$ of $8.9, P$. diadema could not infect anymore although 59\% of the $C$. granii cells had already been infected before (Fig. $4 \mathrm{c}$ ). In this case, the prevalence of infection decreased rapidly, whereas the $\mathrm{pH}$ in the diatom culture increased to a maximum $\mathrm{pH}$ of 9.1.

When $P$. diadema flagellates were added to $C$. granii and or $C$. wailesii cultures with a $\mathrm{pH}$ above 8.8 the flagellates did not infect the diatoms ( $n>10$; not shown). Obviously, a critical value between pH 8.8 and 8.9 existed, above which the flagellates were not infective any more.

Experiment 3: $\mathrm{pH}$ at diatom frustules

In $C$. granii cultures, the distribution of $\mathrm{pH}$ values on the frustule showed at average ambient $\mathrm{pH}$ values of $8.03,8.14$ and 8.22 a normal distribution.
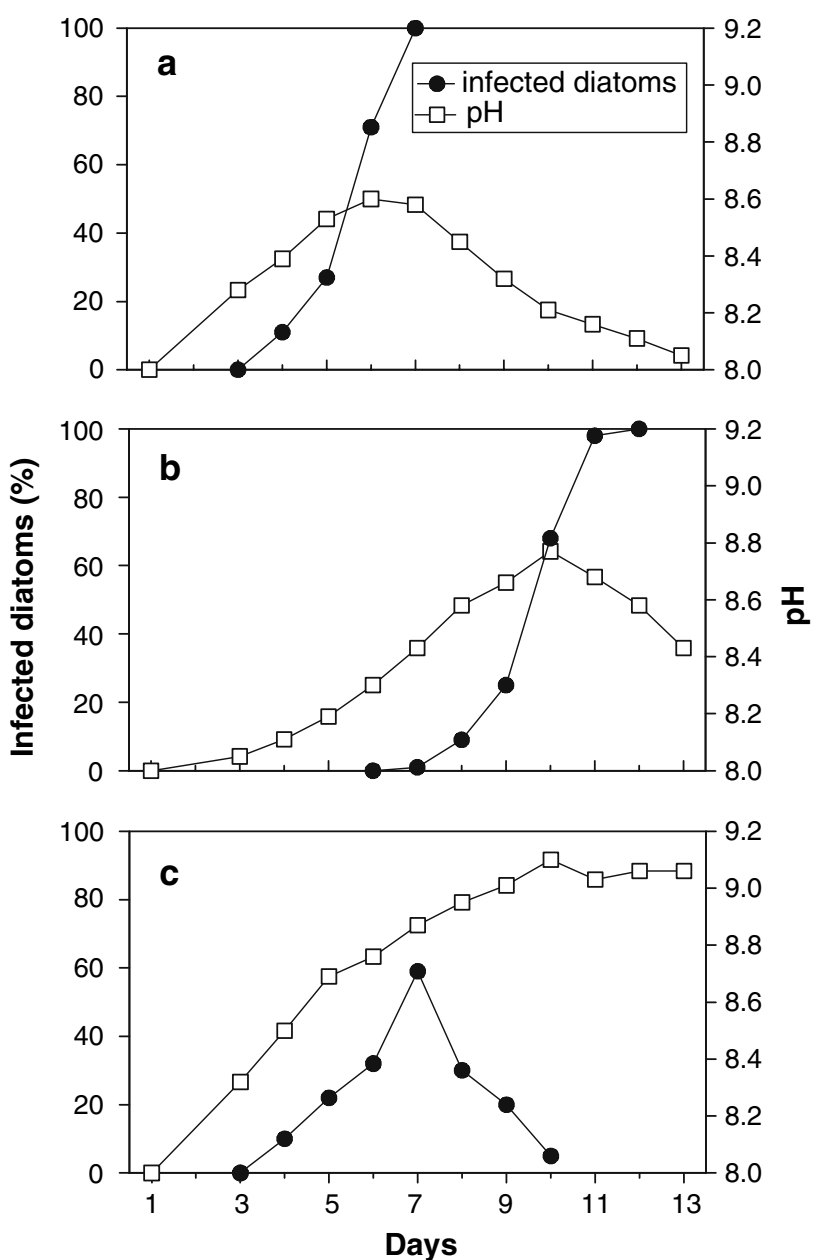

Fig. 4 Coscinodiscus granii batch cultures infected by Pirsonia diadema: development of $\mathrm{pH}$ (open square) and percentage of infected diatoms (filled circle) in single replica. Diatom cultures were inoculated with P. diadema on Day 3 (a, c) and Day 4 (b)

In $85-96 \%$ of the C. granii cells the $\mathrm{pH}$ on the frustule was up to 0.4 units higher than that of the ambient medium (Fig. 5a-c). In 2-3\% of the cells their pH values at the frustule exceeded that of the ambient $\mathrm{F} / 2$ by up to $0.7 \mathrm{pH}$ units, and reached a maximum $\mathrm{pH}$ of 8.95 . Although all diatoms appeared to be healthy, in $2-7 \%$ the surface $\mathrm{pH}$ was not higher than that of the culture medium. On average, the $\mathrm{pH}$ on the frustule was $0.24-0.3 \mathrm{pH}$ units higher than in the culture medium (Fig. 6).

Dividing Coscinodiscus appear as "double" cells before the daughter cells eventually separate. The surface $\mathrm{pH}$ values of these not-yet-divided cells were slightly higher (but not significantly) than those of "single" cells by up to 0.05 units (Fig. 7).

Experiment 4: $\mathrm{pH}$ on frustules of infected Coscinodiscus granii cells versus non-infected cells

The $\mathrm{pH}$ of uninfected $C$. granii was $0.24-0.30 \mathrm{pH}$ units higher than of the ambient seawater. The $\mathrm{pH}$ on the frustule 

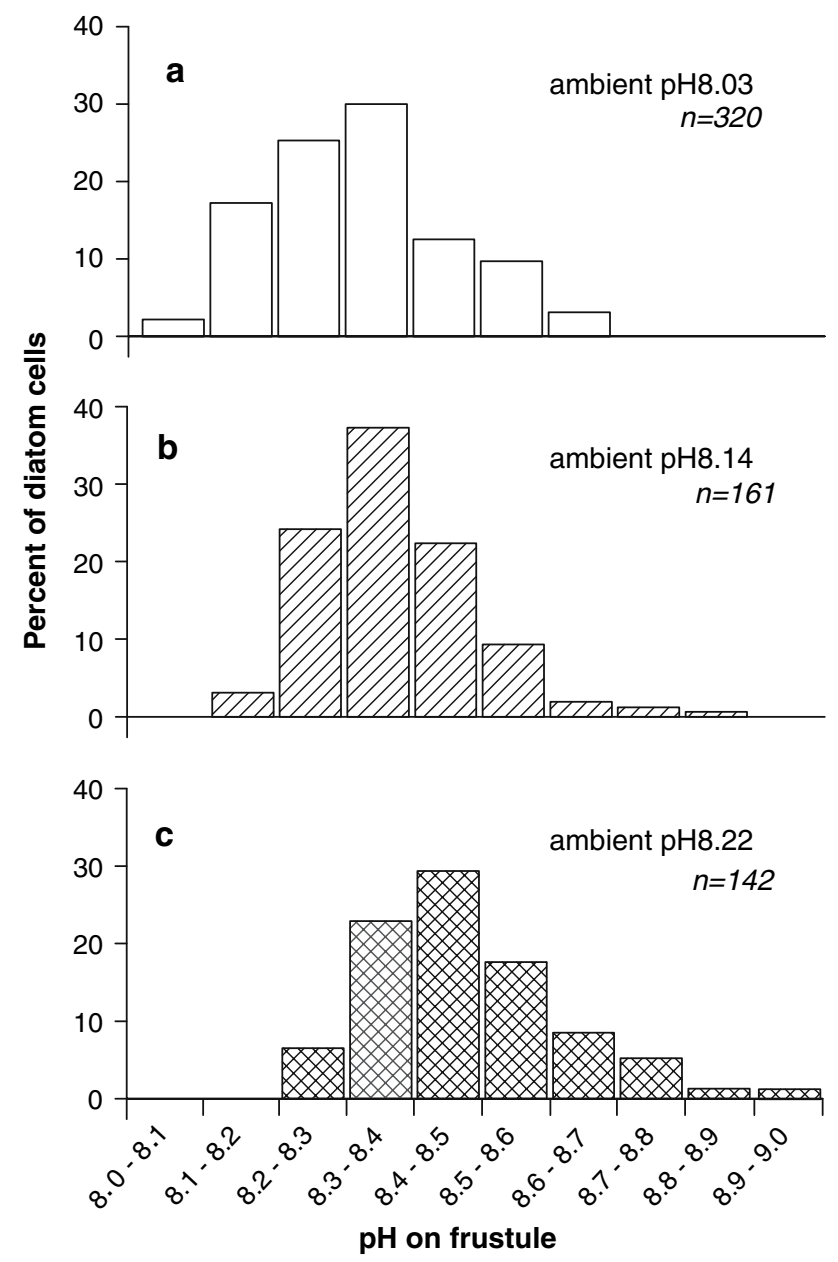

Fig. 5 Surface $\mathrm{pH}$ of Coscinodiscus granii cells at different $\mathrm{pH}$ values of ambient seawater, measured with $\mathrm{pH}$ microsensors

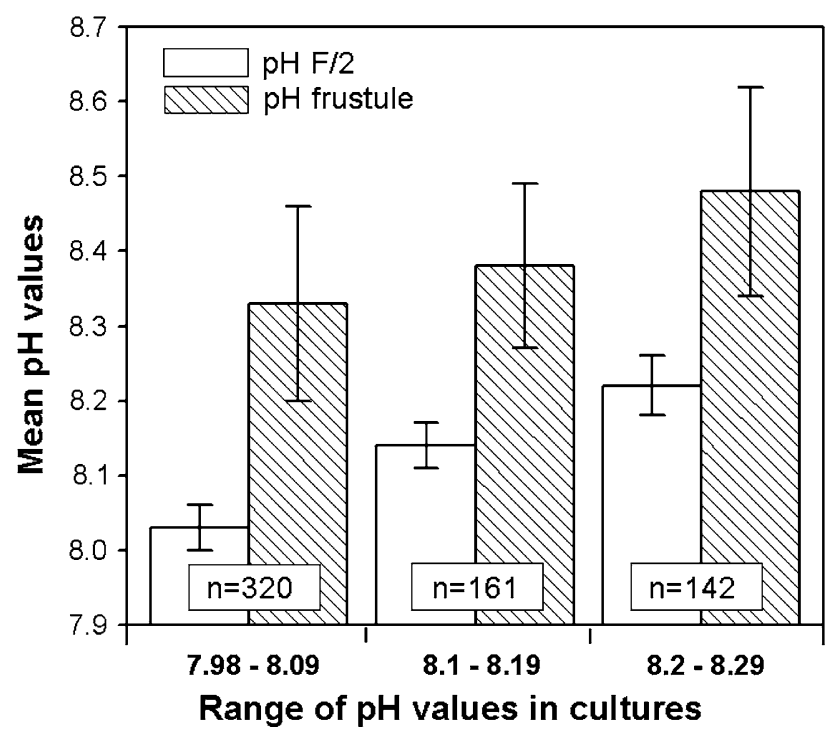

Fig. 6 The $\mathrm{pH}$ of the $\mathrm{F} / 2$ medium varied between 7.98 and 8.29. Measurements at the ranges $\mathrm{pH} 7.98-8.09,8.10-8.19$ and $8.20-8.29$ were grouped together. Mean values $( \pm \mathrm{SD})$ of ambient seawater $(\mathrm{F} / 2) \mathrm{pH}$ and corresponding $\mathrm{pH}$ on the frustule of Coscinodiscus granii are given

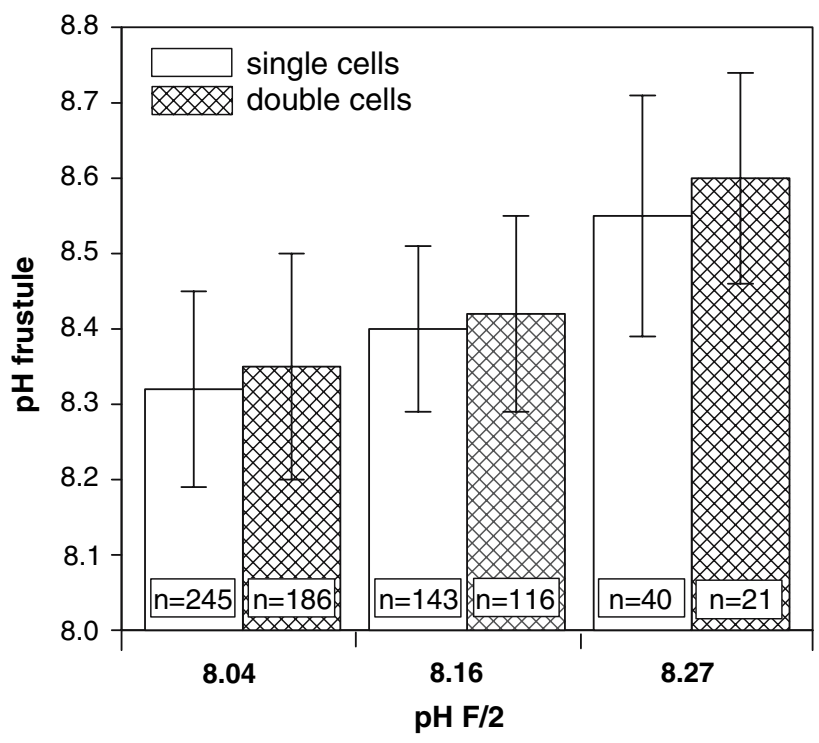

Fig. $7 \mathrm{pH}$ on frustules of Coscinodiscus granii single cells and dividing ("double") cells at different $\mathrm{pH}$ of $\mathrm{F} / 2$. The number of measurements $(n)$ is given at the base of the bar

of uninfected diatoms was always higher than that of infected cells (statistically not significant): the difference increased from $0.06(\mathrm{~F} / 2: \mathrm{pH} 8.04)$ to $0.18 \mathrm{pH}$ units (pH F/ 2: 8.26) (Fig. 8). The differences indicate a trend that with higher ambient $\mathrm{pH}$ Pirsonia preferred host diatoms with low surface $\mathrm{pH}$. Advanced feeding led to progressive reduction of surface $\mathrm{pH}$ (not shown). As $\mathrm{pH}$ was measured shortly after successful infection, feeding flagellates had not yet severely affected the diatoms cytoplasmic structure or taken up extensive amounts of cell contents.

Experiment 5: $\mathrm{pH}$ measurements of vacuole sap

When the $\mathrm{pH}$ microsensor was forced into the vacuole of C. wailesii, generally the protoplast collapsed very rapidly. At an ambient $\mathrm{F} / 2 \mathrm{pH}$ between 7.5 and 8.7, the mean vacuolar $\mathrm{pH}$ was 5.9-6.0, and the lowest values between $\mathrm{pH} 5.44$ and 5.69 (Fig. 9). Only at an average ambient $\mathrm{pH}$ of 7.1, the average vacuolar $\mathrm{pH}$ of 5.5 was lower (lowest value $\mathrm{pH}$ 5.24).

\section{Discussion}

$\mathrm{pH}$ tolerance and dynamics

To investigate the response of microalgae upon changes in their physico-chemical environment most commonly batch cultures are used. It is assumed that cells growing in the same culture have more or less the same physiological properties. In batch cultures of $C$. wailesii, the $\mathrm{pH}$ increased 


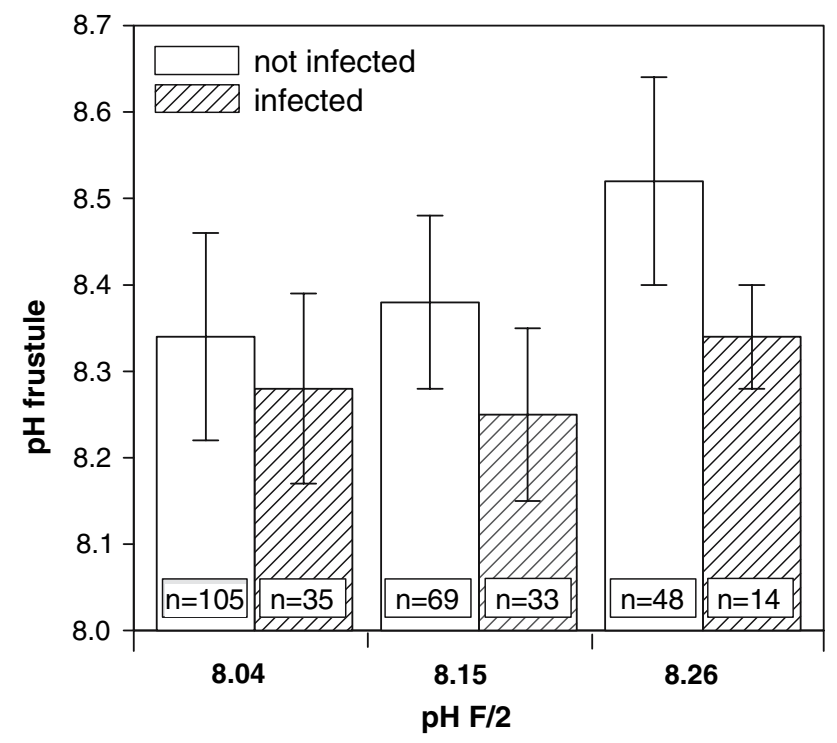

Fig. $8 \mathrm{pH}$ on frustule of infected and non-infected Coscinodiscus granii cells at different $\mathrm{pH}$ of $\mathrm{F} / 2$. The number of measurements $(n)$ is given at the base of the bar

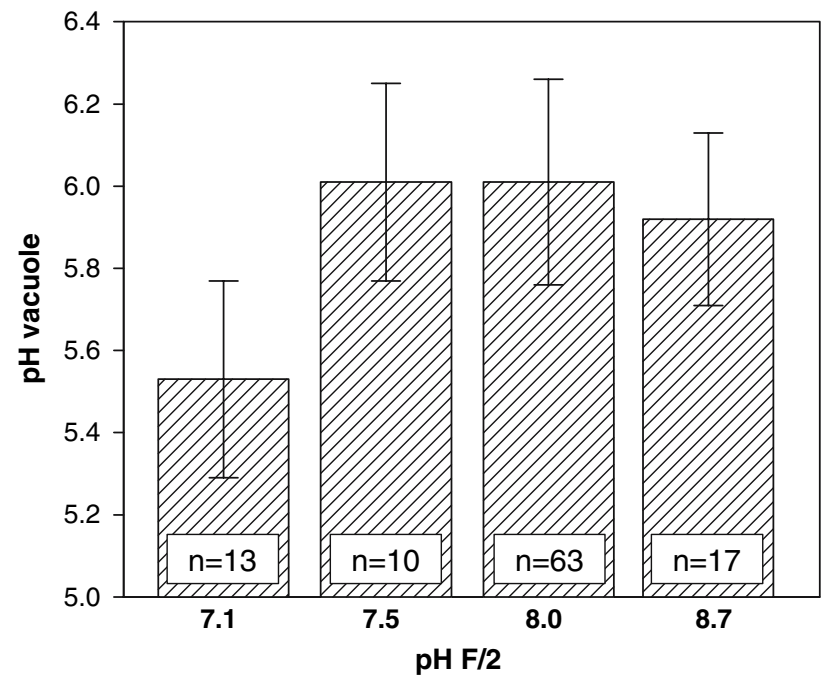

Fig. 9 Microsensor measurements of vacuolar $\mathrm{pH}$ of Coscinodiscus wailesii at different ambient $\mathrm{pH}$

over time and reached a maximum of approximately $\mathrm{pH} 8.8$, whereas $C$. granii cultures tolerated a maximum $\mathrm{pH}$ of 9.1. When $C$. wailesii were transferred into culture medium with a slightly higher $\mathrm{pH}$ value of 9.5 , all cells died within 1-2 days. This indicates that the maximum $\mathrm{pH}$ reached in a Coscinodiscus culture is the maximum $\mathrm{pH}$ tolerated by this species. In cultures of the antarctic diatom Chaetoceros gracile the maximum $\mathrm{pH}$ was 10.3 (Plettner, pers. com.) which corresponds to $\mathrm{pH}$ values as high as 9.9 in antarctic sea ice brine (Gleitz et al. 1995). This confirms the data compiled by Hansen (2002) that the maximum $\mathrm{pH}$ values tolerated by diatoms and other algal groups are species specific.
For $P$. diadema apparently a critical $\sim$ pH 8.8 exists, above which the flagellates do not survive. Since the $\mathrm{pH}$ of natural seawater will not exceed this value, even during phytoplankton mass developments, this $\mathrm{pH}$ limitation will not affect the viability of $P$. diadema under natural conditions.

When in the experimental cultures all Coscinodiscus had been killed by Pirsonia and no photosynthetic activity remained, the $\mathrm{pH}$ of the medium decreased as expected. However, in seawater adjusted to an initial $\mathrm{pH}$ of 8.7, the $\mathrm{pH}$ decreased over 11 days slowly by $0.4 \mathrm{pH}$ units, whereas in infected cultures the $\mathrm{pH}$ decreased more rapidly, i.e. $0.4 \mathrm{pH}$ units within 4 days.

\section{Vacuolar $\mathrm{pH}$}

Previous experiments had shown that P. diadema are chemoperceptive, i.e. flagellates attracted to host cells, were able to distinguish between host species, and preferred already infected diatoms over uninfected cells (Kühn 1997, 1998). A new observation was that flagellates rapidly swam away when $C$. wailesii were crushed manually. This strong negative chemosensory response indicated that $P$. diadema could also sense hydrogen ion concentrations. When a microsensor was pushed into the vacuole of $C$. wailesii this led to a mechanical destruction of the protoplast within a more or less undamaged frustule (e.g. Kühn and Brownlee 2005). Nonetheless, cytoplasm (including vacuole content) was rapidly mixed with culture medium. Since the $\mathrm{pH}$ of the culture medium was higher than the $\mathrm{pH}$ of the vacuole, the $\mathrm{pH}$ measured inside the frustule will tend to overestimate the vacuolar $\mathrm{pH}$. At an ambient $\mathrm{pH}$ of 7.1, the lowest vacuolar $\mathrm{pH}$ measured was $\mathrm{pH}$ 5.2. In contrast, at an ambient $\mathrm{pH}$ 8.7, the lowest value for the vacuolar $\mathrm{pH}$ was 5.6. These results correspond with the results of Kesseler (1967), who used indicator paper and estimated the $\mathrm{pH}$ of $C$. wailesii cell sap to be around 5 . This vacuolar $\mathrm{pH}$ of $\sim 5$ is relatively high compared to e.g. $\mathrm{pH}<1$ in the vacuole of the marine macroalga Desmarestia viridae (McClintock et al. 1982). $\mathrm{pH}$ microsensors cannot be used to determine the vacuole in algae with high turgor: when the microsensor was pressed into the vacuole of Chara sp. (Characeae), the $\mathrm{pH}$ sensitive LIX-matrix at the microsensor tip was very rapidly pushed back into the shaft by the cell turgor (not shown). However, this has never occurred in Coscinodiscus, which confirms observations by Kühn and Brownlee (2005) that the turgor of Coscinodiscus is low.

\section{Effect of $\mathrm{pH}$ on infection}

Since $P$. diadema did not survive $\mathrm{pH}$ above 8.8 , it appears reasonable that flagellates should respond with a negative chemokinetic response to high $\mathrm{pH}$. The $\mathrm{pH}$ microsensor 
experiments showed that at natural $\mathrm{pH}$ conditions of $\mathrm{pH}$ 8.0-8.3, the $\mathrm{pH}$ at the frustule of most Coscinodiscus cells was approximately up to 0.4 units higher than the ambient seawater. Only in $2-3 \%$ of the $C$. granii cells the $\mathrm{pH}$ on the frustule exceeded that of the seawater by up to $0.7 \mathrm{pH}$ units, and reached maximum values of $\mathrm{pH} 8.95$. If $P$. diadema actively avoids high $\mathrm{pH}$, obviously these individual diatoms should not get infected. Previous experiments had shown that about $1 \%$ of $C$. granii cells remained uninfected by $P$. diadema for some time (Kühn 1998), which corresponds with the results of the present study. Apparently, very high $\mathrm{pH}$ values on the frustule deter Pirsonia from infecting. Our experiments also showed that flagellates preferred diatoms with low surface $\mathrm{pH}$. Interestingly, the $\mathrm{pH}$ difference between infected and uninfected cells increased with the $\mathrm{pH}$ increase of seawater. This supports the hypothesis that $P$. diadema selects host diatoms according to their photosynthetic activities. During phytoplankton blooms the $\mathrm{pH}$ of natural seawater can increase to $\mathrm{pH}$ 8.7. In this case, the $\mathrm{pH}$ on the frustule of Coscinodiscus easily may reach $\mathrm{pH} 8.9$ (we measured maximum values of $\mathrm{pH}$ 9.5; publication in preparation). These cells will, at least temporarily, be avoided by Pirsonia.

Richardson and Stolzenbach (1995) showed by means of a chemical reaction (extracellular reaction of oxidised manganese with the dye leukoberbelin blue) that individual phytoplankton cells changed the $\mathrm{pH}$ of their microenvironment by photosynthesis. They also found out that the size of the phycosphere depended on the cell size. $\mathrm{A} \mathrm{pH}$ increase up to 8.6 has been found in the microenvironment of foraminifera due to the photosynthetic activity of their symbiotic diatoms (Köhler-Rink and Kühl 2000).

It is general knowledge that phytoplankton cells release amino acids and carbohydrates and thus produce extracellular microenvironments or phycospheres (Hellebust 1974; Fogg 1983). Coscinodiscus has been reported to contain high internal concentrations of amino acids, which are released as well as carbohydrates (Admiraal 1984; MartinJézéquel et al. 1988; Malej and Harris 1993). If the exudation of individual Coscinodiscus cells depends on their photosynthetic activity, a high surface $\mathrm{pH}$ on cells could correlate with an increased excretion of organic substances noxious to $P$. diadema.

\section{Concept of individuality of diatom cells}

It is generally assumed that diatom populations are a homogenous assemblage of identical cells. Laboratory experiments on the intraspecific selectivity of the parasitoid $P$. diadema, however, indicated that host diatoms temporarily differed in their individual physiological properties and hence the susceptibility to infections (Kühn 1997, 1998). Coates and Park (2002) reported that, for reasons unknown, some specimens of the mixotrophic dinoflagellate host Karlodinium micrum were apparently resistant to infection by the parasitic dinoflagellate Amoebophrya. In the field, encounters between parasitoids and potential host are always encounters between individual organisms, and the current state of one partner may decide about the survival of the other. For example, fully fed or starved parasitoids may not infect diatoms. The "fitness" of individual diatom cells, however, is more difficult to assess.

In natural populations (and most laboratory cultures) diatom growth is not synchronous so that most cells are at different stages of the cell cycle. So far, there is no indication on how the life cycle may affect the physiological properties of individual cells. Chisholm et al. (1980) reported a large non-genetic variability in generation times in clonal diatom populations and concluded "that population growth rates do not reflect the experience of the individual cells in the population". The perception of "individualism" among unialgal cultures was supported by the observation of Du Preetz and Bate (1992) that some individual cells of the diatom Anaulus discus were capable of surviving prolonged darkness, whereas other cells died. Based on differences in the integrity of the plasma membrane Veldhuis et al. (2001) demonstrated a considerable intraspecific variation in cell viability in diatom populations. Differential sinking of cells in diatom cultures was reported by Brzezinski and Nelson (1988).

Here we have demonstrated that the $\mathrm{pH}$ on the frustule of individual $C$. granii cells differed by up to 0.7 units (mean ambient $\mathrm{pH} 8.0-8.2$ ), which strongly indicates variable photosynthetic activities. Maximum surface $\mathrm{pH}$ values were found in $1-3 \%$ of the diatom cells which is concordant with the percentage of cells reported to be temporarily resistant to infections (Kühn 1998). Photosynthetic oscillations were observed in less than $1 \%$ of the $C$. wailesii cells examined (Kühn and Raven 2008). It was suggested that in diatom populations the photosynthetic, physiological and metabolic properties of individual cells differed, at least temporarily.

Even subtle differences between individual phytoplankton cells could determine whether they become prey to heterotrophic organisms or not. Discriminant chemoperceptive feeding behaviour in several protozoans was reviewed by Verity (1991). Jacobson and Anderson (1996) stated that, generally, feeding behaviour studies of heterotrophic organisms, such as dinoflagellates, tend to neglect the physiological condition of the food organism.

\section{Conclusions}

This study showed for the first time that unicellular diatoms in a batch culture differ in their individual photosynthetic 
activities, as indicated by individual $\mathrm{pH}$ values on their surfaces in the light. Monitoring the $\mathrm{pH}$ on the frustule of individual diatoms for several days could reveal if photosynthetic activities depend on different stages in their cell division cycles. Apparently, increased $\mathrm{pH}$ values on Coscinodiscus frustules prevent the cells to be infected by Pirsonia. In regard to their attractiveness for parasitoids or predators small differences in the competitive fitness could determine whether individual microalgae survive or not. It remains to be investigated if cells of chain-forming diatoms, which divide synchronously, are homogenous in their physiological properties.

\section{References}

Admiraal W (1984) The ecology of estuarine sediment-inhabiting diatoms. Prog Phycol Res 3:269-322

Brzezinski MA, Nelson DM (1988) Differential cell sinking as a factor influencing diatom species competition for limiting nutrients. J Exp Mar Biol Ecol 119:179-200

Chisholm SW, Morel FMM, Slocum WS (1980) Phasing and distribution of cell division cycles in marine diatoms. In: Falkowsky PG (ed) Primary productivity of the sea. Plenum Publishing Corp., New York pp 281-299

Coats DW, Park MG (2002) Parasitism of photosynthetic dinoflagellates by three strains of Amoebophrya (Dinophyta): parasite survival, infectivity, generation time, and host specificity. J Phycol 38:520-528

de Beer D, Glud A, Epping E, Kühl M (1997) A fast responding $\mathrm{CO}_{2}$ microelectrode for profiling in sediments, microbial mats and biofilms. Limnol Oceanogr 42:1590-1600

Du Preez DR, Bate BC (1992) Dark survival of the surf diatom Anaulus australis Drebes et Schulz. Bot Mar 35:315-319

Fogg GE (1983) The ecological significance of extracellular products of phytoplankton photosynthesis. Bot Mar 26:3-14

Gleitz M, van der Loeff MR, Thomas DN, Dieckmann GS, Millero FJ (1995) Comparison of summer and winter inorganic carbon, oxygen and nutrient concentrations in Antarctic sea ice brine. Mar Chem 1284:81-91

Goldman JC, Azov Y, Riley CB, Dennett MR (1982) The effect of pH in intensive microalgal cultures. I. Biomass regulation. J Exp Mar Biol Ecol 57:1-3

Guillard RRL, Ryther JH (1962) Studies of marine planktonic diatoms. Can J Microbiol 8:229-239

Hansen PJ (2002) Effect of high pH on the growth and survival of marine phytoplankton: implications for species succession. Aquat Microbial Ecol 28:279-288

Hellebust JA (1974) Extracellular products. In: Steward ND (ed) Algal physiology and biochemistry. University of California Press, Berkeley, pp 838-863

Jacobson DM, Anderson DM (1996) Widespread phagocytosis of ciliates and other protists by marine mixotrophic and heterotrophic thecate dinoflagellates. J Phycol 32:279-285
Kesseler H (1967) Untersuchungen über die chemische Zusammensetzung des Zellsaftes der Diatomee Coscinodiscus wailesii (Bacillariophyceae, Centrales). Helgoländer wiss Meeresunters 16:262-270

Köhler-Rink S, Kühl M (2000) Microsensor studies of photosynthesis and respiration in larger foraminifera. I. The physico-chemical microenvironment of Marginopora vertebralis, Amphistegina lobifera, and Amphisorus hemprichii. Mar Biol 137:473-486

Kühn SF (1997) Infection of Coscinodiscus spp. by the parasitoid nanoflagellate Pirsonia diadema: I. Behavioural studies on the infection process. J Plankton Res 19:791-804

Kühn SF (1998) Infection of Coscinodiscus spp. by the parasitoid nanoflagellate Pirsonia diadema: II. Selective infection behaviour for host species and individual host cells. J Plankton Res 20:443454

Kühn SF, Hofmann M (1999) Infection of Coscinodiscus spp. by the parasitoid nanoflagellate Pirsonia diadema: III. Effects of turbulence on the incidence of infection. J Plankton Res 21:2323-2340

Kühn SF, Brownlee C (2005) Membrane organisation and dynamics in the marine diatom Coscinodiscus wailesii (Bacillariophyceae). Bot Mar 48:297-305

Kühn SF, Raven JA (2008) Photosynthetic oscillation in individual cells of the marine diatom Coscinodiscus wailesii (Bacillariophyceae) revealed by microsensor measurements. Photosynth Res 95:37-44

Kühn SF, Drebes G, Schnepf E (1996) Five new species of the nanoflagellate Pirsonia in the German Bight, North Sea, feeding on planktic diatoms. Helgoländer Meeresunters 50:205-222

Malej A, Harris RP (1993) Inhibition of copepod grazing by diatom exudates: a factor in the development of mucus aggregates? Mar Ecol Prog Ser 96:33-42

Martin-Jézéquel V, Poulet SA, Harris RP, Moal J, Samain JF (1988) Interspecific and intraspecific composition and variation of free amino acids in marine phytoplankton. Mar Ecol Prog Ser 44:303313

Matsuda Y, Hara T, Colman B (2001) Regulation of the induction of bicarbonate uptake by dissolved $\mathrm{CO}_{2}$ in the marine diatom Phaedactylum tricornutum. Plant Cell Environ 24:611-620

McClintock M, Higinbotham N, Uribe EG, Cleland E (1982) Active, irreversible accumulation of extreme levels of $\mathrm{H}_{2} \mathrm{SO}_{4}$ in the brown alga, Desmarestia. Plant Physiol 70:771-774

Pegler K, Kempe S (1988) The carbonate system of the North Sea: Determination of alkalinity and $\mathrm{TCO}_{2}$ and calculation of $\mathrm{PCO}_{2}$ and Sical (Spring 1986). Mitt geol-paläont Inst Univ Hamb 65:35-87

Richardson LL, Stolzenbach KD (1995) Phytoplankton cell size and the development of microenvironments. FEMS Microbiol Ecol 16:185-192

Taguchi S, Hirata JA, Laws EA (1987) Silicate deficiency and lipid synthesis of marine diatoms. J Phycol 23:260-267

Tortell PD, Reinfelder JR, Morel FMM (1997) Active uptake of bicarbonate by diatoms. Nature 390:243-244

Veldhuis MJW, Kraay GW, Timmermans KR (2001) Cell death in phytoplankton: correlation between changes in membrane permeability, photosynthetic activity, pigmentation and growth. Eur $\mathbf{J}$ Phycol 36:167-177

Verity PG (1991) Feeding in planktonic protozoans: Evidence for nonrandom acquisition of prey. J Protozool 38:69-76 